\title{
ECHA ZABIEGÓW STOLICY APOSTOLSKIEJ OKOŁO ZAKOŃCZENIA ROZLAMU ZE WSCHODEM W KORESPONDENCJI ŚW. AWITA Z VIENNY I PAPIEŻA HORMIZDASA
}

Św. Awit (450-518) należy do tych czołowych postaci zachodniego episkopatu, które po upadku rzymskiego imperium podjęły znojny trud kształtowania nowego oblicza Europy w oparciu o te ludy, dla których nastał wówczas historyczny świt ${ }^{1}$. W trud ten wpisane były jego starania, dotyczące zwycięstwa prawdziwej wiary wśród jednego z tych ludów - Burgundów, który osiedliwszy się najpierw nad Renem, a potem w Sabaudii, toczył w swoim łonie walkę katolicyzmu z herezją ariańską ${ }^{2}$. Wieloletnia przyjaźń biskupa z Vienny z królem burgundzkim Gundobadem (480-516) zaowocowała tym, że syn królewski Zygmunt, następca tronu, przyjął katolicką wiarę. Ten późniejszy święty i męczennik, jako władca respektujący zasadę ewangeliczną, iż panowanie jest służbą, szczerze zabiegał o rozwój katolicyzmu wśród swego ludu. Czynił to w oparciu o ścisły związek z papieskim Rzymem, co znalazło swój wyraz między innymi w jego pielgrzymce do Wiecznego Miasta ${ }^{3}$. I choć splot dziejowych wydarzeń sprawił, że to nie Burgundom, ale Frankom przypadła główna rola w budowaniu przyszłości średniowiecznej Europy, to przecież i do nich popłynęła swym życiodajnym strumieniem antyczna kultura wprost z jej źródła Rzymu św. Piotra. Zasługa wobec tego wydarzenia przypadła w znacznej mierze również św. Awitowi ${ }^{4}$. Lecz ten święty, będąc tak zaangażowany w krzewienie katolicyzmu wśród ludów na Zachodzie, czynił to w powiązaniu z życiem całego Kościoła, również z tym, co działo się na Wschodzie.

Wśród jego bogatej korespondencji ${ }^{5}$, świadczącej o różnorodności jego zainteresowań, znajduje się list zdradzający swą treścią żywą troskę tego zachodniego biskupa o jedność „niepodzielnej szaty Chrystusa”. List ten, w ko-

${ }^{1}$ Por. B. Zientara, Świt narodów europejskich, Warszawa 1996, 77.

2 Por. Socrates, HE VII 30, PG 67, 805, thum. S. Kazikowski: Sokrates Scholastyk, Historia Kościoła, Warszawa 1986, 539.

${ }^{3}$ Por. B. Altaner - A. Stuiber, Patrologia, tłum. A. Pachciarek, Warszawa 1990, 617.

${ }_{5}^{4}$ Por. A. Bober, Antologia patrystyczna, Kraków 1965, 354.

5 Trafnie i zwięźle sztukę epistolarną Awita, na podstawie kilkudziesięciu zachowanych listów, ocenił K. Morawski, Zarys literatury rzymskiej, Warszawa 1922, 398-399. 
respondencji Awita 87, znany jako Exemplum relationis Aviti episcopi Galiae, skierowany do papieża Hormizdasa (515-523), dotyczy otwartego rozłamu między Rzymem a Konstantynopolem, jaki miał miejsce na przełomie V i VI stulecia $^{6}$. Świadczy on o dobrej orientacji autora, co do papieskich poczynań odnośnie zakończenia zaistniałego rozłamu. Podziwia w nim Awit wszechstronność zabiegów papieskich, elastyczność i takt legacji rzymskiej, która w oparciu o papieską formułę wiary umiała zjednać dla jedności, kościelną społeczność Grecji, Dardanii i Ilirii. Z czasem ta obowiązująca w całym Kościele „regula fidei” położy kres schizmie na Wschodzie, a na Zachodzie zapobiegnie ewentualnym niepożądanym rozłamom.

List Awita jest pod tym względem bardzo interesujący, a uważny czytelnik z satysfakcją odnajdzie w nim dyskretne przekonanie jego autora o prymacie Stolicy Apostolskiej, która w kwestii czystości wiary jest jej obrończynią: stanowi to subtelny motyw przewodni w całości jego treści. Już na początku listu Awit, pisząc o papieskiej trosce o prawdziwą wiarę, wyraźnie wskazuje, że dotyczy ona całego Kościoła:

„Konieczne jest dla dobra religii i zachowania zasad katolickiej wiary, aby owczarnię Pańską i wszystkich chrześcijan powszechnego Kościoła pouczała czujna troska waszych instrukcji. Tak czyniliście w ubiegłym roku w stosunku do prowincji Vienny w listach skierowanych do mnie, jakie szczęśliwym zbiegiem okoliczności docierały do mnie przez duchownych Kościoła w Arles: dają one wyraz szczególnej papieskiej troski" ${ }^{\prime}$.

Następnie dziękując papieżowi za jasną wykładnię wiary zawartą w jego pouczeniach, z pewnym niepokojem oczekuje na wieści dotyczące rezultatów misji papieskiej na Wschodzie. Z tego też powodu wysyła dwóch posłańców, aby ci w Rzymie uzyskali potrzebne informacje:

„Zechcieliście zakomunikować nam radość z nawrócenia się prowincji Dardanii, Illirii i Scytii dołączając instrukcję i uprzedzając przed niebezpieczeństwami w jakie wpadlibyśmy przez ignorancję ${ }^{8}[\ldots]$. Zaś to nas niepokoi, że chociaż nakazaliście

${ }^{6}$ Por. Avitus, Epistola 87: Exemplum relationis Aviti, episcopi Galli, ed. O. Guenther, w: Collectio Avellana: Epistulae imperatorum, Pontificum et aliorum (an. 367-553), nr 136, CSEL 35, 558-560, lub PL 59, 288-290.

7 Exemplum relationis 1, CSEL 35, 558-559: „Dum religionis statui et plenis catholicae fidei regulis perspicitis convenire, ut gregem per tota vobis universalis Ecclesiae membra commissum pervigil cura vestrae adhortationis informet, Viennensem provinciam superiore anno, si meminisse dignamini, datis ad humilitatem meam litteris visitastis, quaeque ad me, secundum quod oportunitas oblata contulerat, per Arelatensis Ecclesiae clericos pervenerunt et quidem plenissimae sollicitudine pastorali".

8 Awit ma zapewne na myśli zgromadzenie około 40 biskupów z Ilirii i Grecji, a także biskupów Dardanii, którzy wysłali do Rzymu listy, w jakich zapewniali o poddaniu się regułom Stolicy Apostolskiej, por. Theophanes, Chronographia, PG 108, 378. Zob. też list papieża Hormizdasa do Cezarego z Arles, gdzie papież pisze (PL 63, 432): „Ergo episcopi tam Dardani, quam 
nam oczekiwać na wynik tego, czego dostarczą nam wasi legaci z Konstantynopo$\mathrm{la}^{9}$, nie wiemy, co przyniósł stamtąd wasz syn a mój brat Ennodiusz; czy powrócił osiągnąwszy to, co było oczekiwane ${ }^{10}$. Obiecane nam powiadomienie dotąd nie dotarło. I niemniej nas wprawia w niepokój owo milczenie wysłańca, jak poprzednio wydawała się nam podejrzana zwłoka ze strony legatów. Ta przyczyna zmusza mnie, że w imieniu całej prowincji wieneńskiej wysyłam z listem posłów [...], abym za ich pośrednictwem uzyskał wyjaśnienie Stolicy Apostolskiej"11.

Kolejny fragment listu Awita ukazuje tak charakterystyczną dla niego troskę duszpasterza o czystość wiary katolickiej, wolnej od jakiejkolwiek skazy:

„Pragniemy wiedzieć, czy zaciekłość schizmy wyżej wymienionych, która objęła Konstantynopol, a także Kościoły Aleksandrii i Antiochii, pod wpływem waszych pouczeń i za łaską Chrystusa została stłumiona"12.

\title{
Obawa, czy zasłyszane wieści o jedności Wschodu ze Stolicą Apostolską nie są tylko pogłoskami, każe mu następnie zwrócić się do papieża o pouczenie:
}

\begin{abstract}
„Dodaję, że jak dowiedzieliśmy się z różnych godnych wiary relacji, Grecy chełpią się z osiągnięcia pojednania i zgody z Kościołem Rzymskim. Tak jak trzeba się cieszyć, gdy to jest prawdą, tak też należy się obawiać, czy nie jest to chytry podstęp. Proszę więc o pouczenie, co mam powiedzieć moim synom Gallom, gdy będę pytany. Nie mogę być pewny prowincji Vienny, tym bardziej całej Galii, obiecuję jednak zjednać wszystkich dla naszego orzeczenia o stanie wiary. Módlcie się, aby nas nie wciągnęła w błąd kłamliwa wiara grzeszników, tak jak nas nie oddziela od jedności znana nam prawda, jaką pouczacie Kościół”13.
\end{abstract}

Illyrici pene omnes, ne sint errore condemnandi praeterito, petentes beati Petri apostolorum principia communionem et scriptis et legationibus destinatis se apostolicae sedes regulis obedire confirmant".

${ }^{9}$ Chodzi o legację papieską wysłaną do Konstantynopola w sierpniu 515 roku. W jej skład wchodzili: Ennodiusz - biskup Ticinum, Fortunat - biskup z Katanii, kapłan Wenancjusz, diakon Witalis i notariusz Hilary.

${ }^{10}$ Legaci powrócili zimą 516 r., nie osiągnąwszy porozumienia w stolicy Bizancjum, por. Liber pontificalis, ed. L. Duchesne, Paris 1958, 269.

11 Exemplum relationis 1-3, CSEL 35, 559: „In quibus nos sicut per conversionem provinciarum, id est Dardaniae Hillyrici vel Scythiae, ad communionem gaudiorum provocatis, sic admonitione cautissima, ne quid per ignorantiam praevenire posit, instruitis [...] ut non minus modo praedicatoris taciturnitas reddat attonitos quam antea fecerat legationis mora suspectos. Unde sola causa servos vestros filios meos Alethium presbyterum et Viventium diaconum totius provinciae Viennensis nomine, quae Ecclesiae ad me pertinenti ab universis decessoribus vestris et apostolica sede commissa est, cum praesentis famulatus pagina destinavi, per quos oraculo beatissimae responsionis agnoscam $[\ldots]$ ".

12 Tamże 3, CSEL 35, 559-560: „,...] utrum fervor schismatum praefatorum, qui intra Constantinopolitanam urbem vitio perniciose obstinationis exarserat cuique, quod magis dolendum est, Alexandrinam vel Antiochenam Ecclesias dicitis inligatas, vobis Christo favente docentibus digna fuerit correctione restinctus $[\ldots] "$.

13 Tamże 4-5, CSEL 35, 560: „His adicitur, quod diversorum fida relatione comperimus de reconciliatione vel concordia ecclesiae Romanae iactitare se Graeciam. Quod sicut amplectendum, 
List ten, napisany przez Awita pod koniec 516 r., dostarczyli papieżowi wysłannicy biskupa Vienny, kapłan Alecjusz i diakon Wiwencjusz. Papież otrzymał go 30 stycznia 517 r. i odpowiedział nań piękną nauką. W liście skierowanym do Awita, datowanym na 15 lutego 517 r., zawarł słowa znamionujące niezwykłą umiejętność obejmowania całości spraw Kościoła. Zaangażowany szczególnie mocno w pozytywne rozwiązanie zaistniałego rozłamu ze Wschodem, nie zapomniał o prawidłowym rozwoju Kościoła na Zachodzie, zwłaszcza wśród świeżo rodzących się królestw ludów do niedawna barbarzyńskich $^{14}$. Pochwalając troskę Awita o jedność Kościoła w wierze delikatnie wyjaśnia, dlaczego Rzym nie informował prowincji wieneńskiej o stanie rozmów zjednoczeniowych ze Wschodem:
„Jasno wykazuje twój list, jak gorąco pragniesz być pouczonym o tym, co należy do powinności katolickiej, i jak ci leży na sercu zachowanie Bożych nakazów [...]. Godna pochwały jest też troska wiernych, iż boleją nad upadkiem nieszczęśni- ków, a mają się na baczności, by sami nie zarazili się cudzą epidemią. Nie sądź- cie, że przespaliśmy sprawę nie donosząc wam, jaki jest stan rzeczy. Obecnie wyjaśniamy pokrótce to, co was niepokoiło. Bo po cóż nękać was częstymi uwa- gami, skoro pewni jesteśmy stałości waszej wiary. Tam trzeba dokładać starań, gdzie są wątpiący, doskonałym zaś można darować pouczenia"15.

Po tej pochwale swego adresata, papież w niejakim kontraście do jego postawy pełnej szczerości, ukazuje fałszywość zachowań partnerów wschodnich rozmów zjednoczeniowych, dając jasno do zrozumienia, że one spowodowały impas w tym względzie. Stąd też milczenie papieża, nie mającego do przekazania Awitowi dobrych wieści:

„Co dotyczy Greków, to więcej gadali o pokoju niż chcieli, więcej mówią o sprawiedliwości, niż czynią, chełpią się mówieniem, że chcą, a uczynkami deklarują, że nie chcą. Nie kochają tego, co wyznają, idą za tym, co potępiają [...]. To była przyczyna naszego milczenia. Sami to zrozumiecie, kierowani duchem roztropnoś-

si veraciter dicitur, ita metuendum est, ne callide simuletur. Quaesumus ergo servitio meo cuncti, ut quid filiis vestris fratribus meis, id est Gallicanis, si consular, responderi debeat, instruatis. Quia cum securus non dicam de Viennensi sed de totius Galliae devotione pollicear omnes super statu fidei vestram captare sententiam, orate ut sic nos perditorum professio fucata non fallat, sicut ab unitate, quam regitis, veritas comperta non separat".

${ }^{14}$ Dowodem na to są jego listy do biskupów Zachodu, zwłaszcza Hiszpanii i Galii, por. S. Koczwara, List papieża Hormizdasa (514-523) do wszystkich biskupów Hiszpanii, ABMK 78 (2002) 65-70.

15 Epistola Hormisdae papae ad Avitum episcopum 1-2, w: Collectio Avellana nr 137, CSEL 35, 560-561: „Qui de his, quae ad disciplinam catholicam pertinent, maxime sciens instrui cupit, quid studii circa mandata divina habeat, evidenter ostendit [...]. Digna plane sollicitudo fidelibus, ut de miserorum lapsibus ingemescant et ipsi ne aliena polluantur contagione providebant. Sed ne nos quidem hoc supersedisse credatis, ut ad notitiam vestram, si quid actum fuisset, competens perferret instructio. Verum breviter silentium nostrum, quo dilectio mordetur vestra, purgamus. Nam quod non saepius nostra admonitio vos frequentat, de conscientiae vestrae et fidei stabilitate confidimus. Sollicitudo impendenda fortasse sit dubiis, satis est vitanda indicasse perfectis". 
ci. Bo o czym miałem wam pisać, skoro widziałem u nich podtrzymywaną uporczywie perfidię?"16.

Skoro zdaniem papieża wina w zerwaniu rozmów zjednoczeniowych leżała po stronie Bizancjum, które - jak wyżej wykazano - wprawdzie w słowach zapewniało o jedności, lecz w czynach jej zaprzeczało, to w następnych wierszach listu musiało paść ze strony papieża ostrzeżenie, by Awit i cały galijski episkopat zachował ostrożność, co do zasłyszanych ze Wschodu wieści o jego jedności z Rzymem dając, tym samym przykład roztropności i stałości w wierze. I istotnie, odnajdujemy je w słowach:

„Stąd prosimy cię, Drogi Bracie, a przez ciebie upominamy wszystkich w Galii, wyznających z nami tę samą wiarę: zachowajcie stałość w ukochanej wierze! Unikajcie łączności a heretykami. Tę waszą stałość, jak «czystą dziewicę jednemu mężowi» przekażcie Chrystusowi i czuwajcie, «aby nie uwiódł was wąż swą chytrością jak Ewę», by umysły niektórych nie utraciły swojej prostoduszności i czystości, jaka jest w Chrystusie Panu. Zgubne są pochlebstwa upadłych, dlatego czuwać należy, bo «przeciwnik zbawienia ludzkiego krąży jako lew, szukając, kogo by pożarł. Mocni w wierze przeciwstawcie się jemu»"17.

Są jednak w liście papieskim i radosne wieści, mianowicie informacja, że o ile na głównym froncie rozmów zjednoczeniowych trwał impas, o tyle w prowincjach sąsiadujących bezpośrednio z Bizancjum nastąpił pewien przełom. Papież potwierdza znane już wcześniej Awitowi wieści o powrocie do jedności ze Stolicą Apostolską prowincji Dardanii, Tracji i Illirii. Chwaląc postępowanie wiernych z tychże krain, którzy przeciwstawili się zakusom tych, co nie chcieli porozumienia z Rzymem, pisze z uznaniem:

„Co osiągnęli [Grecy], można poznać przez to, że wielu Traków - chociaż atakują ich swoimi napadami - pozostało w jedności z nami. Wiedzą oni, iż wiara okazuje swą wartość w przeciwnościach. Dardania i Iliria sąsiadujące z Panonią zażądały wyznaczenia dla siebie biskupów, co już uczyniliśmy, gdzie to jest konieczne. A teraz cieszą się z tej rozłąki ze zgubionymi, a szukali sposobów - by nie mieć nic wspólnego

${ }^{16}$ Tamże 4 i 6, CSEL 35, 561- 562: „Sed quantum ad Graecos, ore potius praeferunt pacis vota quam pectore et loquuntur magis iusta quam faciunt ; verbis velle se iactant, quod operibus nolle declarant; quae fuerint professi non diligunt, quae damnaverint haec sequuntur [...]. Haec fuit nostri causa silentii, quam vos quoque spiritali vobis prudentia revelante vidistis. Quid enim de hac causa poteram directis litteris indicare, quam in statu suo videbam duram pertinaciter custodire perfidiam?".

17 Tamże 7-8, CSEL 35, 562 : „Quapropter, dilectissime frater, et vos praesentibus hortamur alloquiis et per vos quoque, quia occasio data est, alios per Gallias, quos fides eadem nobiscum amplectitur, admonemus: promissam et amabilem Deo fidei servate constantiam et transgressorum societate declinata constantiam vestram uni viro virginem castam, sicut spopondistis, exhibete Christo et cavete, ne sicut serpens Evam seduxit astutia sua, ita sensus aliquorum corrumpantur a simplicitate et castitate, quae est in Christo Jesu. Perniciosa sunt blandimenta nocentium atque ideo vigilare vos convenit, quia adversarius salutis humanae sicut leo rugiens circuit quaerens, quaem devoret: cui resistite fortes in fide", por. 2 Kor 11, 2-3 ; 1P 5, 8-9. 
z heretykami.. Metropolita Epiru, biskup Nikopolis niedawno ze swym synodem oderwał się od herezji i wrócił do komunii apostolskiej złożywszy wyznanie"18.

Na koniec biskup Rzymu prosi usilnie, by katolicka społeczność w Galii wsparła tę jedność swoją modlitwą, utwierdzając się sama w prawdziwej wierze:

„Módlcie się za nami i kierujcie do Boga prośby, ażeby nasze starania o trwałość katolickiej wiary przez miłosierdzie Boże mogły przynieść owoce, aby też was zachował od jakiejkolwiek łączności z przestępcami, abyście z nawróconymi złączyli umysły i serca, a od trucizny odstępców mogli być zachowani"19.

Przytoczyliśmy w niniejszym artykule korespondencję między biskupem Vienny Awitem a Stolicą Apostolską. Przetłumaczenie jej na język polski płynęło z przekonania, że jej walory treściowe dobrze oddają troskę zarówno biskupa reprezentującego zachodni episkopat, jak i papieża o jedność Kościoła powszechnego. O tym, że jedność ta była możliwa w oparciu zasady podane przez Stolicę św. Piotra, która jest strażniczką tejże jedności, uważny czytelnik może sam wywnioskować $z$ treści tejże korespondencji.

\section{PASSI DELLA SEDE APOSTOLICA INTORNO EPILOGO DI DIVISIONE CON ORIENTE NELLA CORRISPONDENZA S. AVITO DI VIENNE E PAPA ORMISDA}

(Riassunto)

S. Avito di Vienne fu una figura eminente nella Chiesa delle Occidente tra il V e il VI secolo. Sua sede episcopale di Vienne si trovava nel territorio dei Burgundi, che erano ariani. In genere, la lotta contro le eresie e la preoccupazione per l'unità della Chiesa furono le caratteristiche della sua azione pastorale. A nome dell'episcopato della Gallia assicurò papa Ormisda (515-523) che la Gallia sulla questione con l'Oriente (lo scisma acaciano) avrebbe seguito le sue decisioni, dando ampio riconoscimento del primato della Sede Apostolica.

18 Tamże 10, CSEL 35, 563: „Ut autem, quae sint partium earum studia, possitis agnoscere, plures Thracum, licet persequentium incursibus atterantur, in nostra tamen communione persistunt scientes fieri fidem per adversa clariorem. Dardania et Hillyricus vicina Pannoniae a nobis, quod iam fecimus ubi neccesarium fuit, ut sibi episcopi ordinarentur, expetiit, in tantum se a consortio perditorum separare gaudentes, ut remedia quaererent, dummodo commune cum transgressoribus nihil haberent. Epiri metropolitanus, hoc est Nicopolitanus episcopus, cum synodo sua nuper segregatus ab impiis ad apostolicam communionem deprompta, quae id efficeret, professione se contulit".

19 Tamże 13, CSEL 35, 563-564: „Vos orate et nobiscum ad Deum preces et vota coniungite, ut per opem misericordiae eius nostra actio laborans pro catholicae fidei stabilitate promoveat, immaculatos vos et integros ab omni transgressorum societate servantes, ut aut cum correctis sensus et corda iungamus aut ab eorum venenis intacti esse mereamur". 